\title{
Articulation and Backside Wear Analysis after Long-Term in vitro Wear Simulation of Vitamin E Stabilized Polyethylene Acetabular Liners with a Press-Fit Locking Mechanism
}

\author{
A.L. Puente Reyna ${ }^{1,2}$, M. Holderied ${ }^{1}$, M. Jäger ${ }^{3}$, C. Schilling ${ }^{1}$, T.M. Grupp ${ }^{1,2}$ \\ ${ }^{1}$ Aesculap AG, Research \& Development, 78532 Tuttlingen, Germany \\ ${ }^{2}$ Ludwig Maximilians University Munich, Department of Orthopaedic Surgery, Physical Medicine \& Rehabilitation, \\ Campus Grosshadern Munich, 81377 Munich, Germany \\ ${ }^{3}$ Department of Orthopaedics and Trauma Surgery, University of Duisburg-Essen, 45147 Essen, Germany
}

\begin{abstract}
A previous retrieval study analyzed the backside wear of short-term implanted liners against in vitro tested liners of similar life in service and showed comparable results among both groups, with no significant backside wear due to micro-motion.

The purpose - to obtain a picture of the overall wear (articulation and backside surfaces) of $0.1 \%$ vitamin $\mathrm{E}$ blended polyethylene liners, with a locking mechanism based on a press-fit cone in combination with a rough titanium conical inner surface in the fixation area, under a 20 million cycles hip wear simulation.

Materials and Methods. A semi-quantitative method was used in order to assess the damage on the backside of the liners and a 3D measuring machine to assess the creep and wear at the articulation surface.

Results. The total average backside wear score was $22.00 \pm 2.59$ from a maximum total score of 147 after 5 million cycles (mc), increased to $31.92 \pm 5.57$ after $10 \mathrm{mc}$, but showed no further increment after 15 and 20 mc. The reference liners (subjected only to axial load) showed similar wear scores and modes as the liners under wear simulation (axial load and movement). Small scratches produced during insertion and removal were clearly seen at the rim (fixation) area and no considerable abrasion was observed. The machining marks on the convex surface were always visible. Regarding the articulation surface, a steady state wear rate of $7 \mu \mathrm{m} /$ year was measured.

Conlusion. These results determined that most of the backside wear produced on the liners occurred during their insertion and removal rather than during their life in service. Moreover, the wear at the articulation surface was similar to that seen in vivo at short- and mid-term on highly cross-linked polyethylene liners with and without vitamin E content.
\end{abstract}

Keywords: total hip arthroplasty, wear simulation, vitamin E, backside wear.

DOI: $10.21823 / 2311-2905-2018-24-2-29-40$

Cite as: Puente Reyna A.L., Holderied M., Jäger M., Schilling C., Grupp T.M. Articulation and Backside Wear Analysis after Long-Term in vitro Wear Simulation of Vitamin E Stabilized Polyethylene Acetabular Liners with a Press-Fit Locking Mechanism. Travmatologiya i ortopediya Rossii [Traumatology and Orthopedics of Russia]. 2018;24(2):29-40. (in Russian). DOI: 10.21823/2311-2905-2018-24-2-29-40.

$\triangle$ Ana Laura Puente Reyna. 78532 Tuttlingen, Germany; e-mail: ana_laura.puente_reyna@aesculap.de Received: 21.03.2018. Accepted for publication: 14.05.2018. 


\title{
Анализ износа артикулирующей и тыльной поверхностей после долгосрочного in vitro моделирования износа стабилизированных витамином Е полиэтиленовых вкладышей с пресс-фит блокированием
}

\author{
A.L. Puente Reyna ${ }^{1,2}$, M. Holderied ${ }^{1}$, M. Jäger ${ }^{3}$, C. Schilling ${ }^{1}$, T.M. Grupp ${ }^{1,2}$ \\ ${ }^{1}$ Aesculap AG, Research \& Development, 78532, Туттлинген, Германия \\ 2 Университет им. Людвига Максимилиана, 81377, Мюнхен, Германия \\ ${ }^{3}$ Университет Дуйсбург-Эссен, 45147, Эссен, Германия
}

\section{Реферат}

Предыдущие исследования были посвящены износу тыльной поверхности кратковременно имплантированных вкладышей в сравнении со вкладышами, тестируемыми in vitro, в течение равного количества времени. В результате были продемонстрированы сравнимые результаты в обеих группах, при этом не было отмечено существенного износа тыльной поверхности вследствие микроподвижности.

Цель исследования - получить данные об общем износе (артикулирующей поверхности и тыльной поверхности) полиэтиленовых вкладышей, стабилизированных 0,1\% витамином Е, которые блокировали за счет пресс-фит посадки в шероховатой титановой внутренней поверхности чашки. Условия моделирования износа составляли 200 миллионов циклов движений тазобедренного сустава.

Материал и методы. Для оценки степени повреждения тыльной поверхности вкладышей использовали полуколичественный метод. Степень износа сочленяющихся поверхностей определяли с использованием 3D координатно-измерительного прибора.

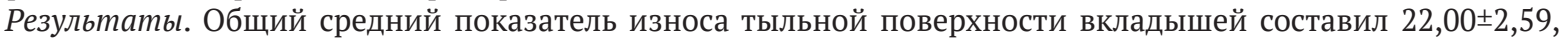
максимальный общий показатель составил 147 после 5 млн циклов. Авторы наблюдали увеличение среднего показателя до 31,92 5,57 через 10 млн циклов, при этом, дальнейшего увеличения показателей через 15 и 20 млн циклом не отмечали. Контрольные вкладыши (подверженные только аксиальной нагрузке) продемонстрировали схожие показатели и модели износа как вкладыши, подверженные моделированию износа (аксиальная нагрузка и движение). Небольшие царапины, нанесенные во время установки и удаления вкладышей, были четко видны в области фиксации, при этом значимого абразивного истирания не было отмечено. Всегда были видны риски на выпуклой поверхности вкладышей. Скорость износа сочленяющихся поверхностей составила 7 мкм/год.

Bыводы. Результаты исследования продемонстрировали, что основной объем износа тыльной стороны вкладышей происходит в процессе их установки и удаления, нежели в период функционирования протеза. Более того, объем износа артикулирующей поверхности был идентичен объему износа, который отмечали in vivo при кратко- и среднесрочной имплантации вкладышей из кросс-линк полиэтилена с высокими поперечными связями без или с добавлением витамина Е.

Ключевые слова: тотальное эндопротезирование тазобедренного сустава, моделирование износа, витамин Е, износ тыльной стороны вкладыша.

DOI: $10.21823 / 2311-2905-2018-24-2-29-40$

\section{Introduction}

Aseptic loosening as a consequence of wear generated particulate debris remains the principal reason for revision in total hip arthroplasty at the long-term [1]. The main source of particulate debris, and thus the most studied, is at the articulation surface. However, the wear produced at the interface between the liner and the metallic acetabular component, known as backside wear, gained importance after high revision rates due to retroacetabular osteolysis were seen on retrieved liners showing high backside wear [2-6]. When there is an unstable locking mechanism and a poor conformity between the liner and the acetabular shell, wear is produced at this non-articulating surface as a result of micro-motions between both components [7-9]. Therefore, a secure locking mechanism should be able to decrease the backside wear to values that do not substantially contribute to the overall wear rate of polyethylene liners $[9,10]$.

A previous retrieval study analyzed the backside wear of acetabular liners with a locking mechanism based on a press-fit cone with a large surface area in combination with a grit blasted rough titanium inner surface along the rim of the acetabular shell [11]. In the study, the backside wear of short-term retrievals made out of conventional standard polyethylene (CPE), highly cross-linked polyethylene (XLPE) and highly crosslinked and vitamin E (0.1\%) blended polyethylene was analyzed and compared with their corresponding in vitro tested liners of equivalent life in service, showing similar results among both groups and no significant backside wear due to micro-motion. 
A limitation of the study was that the analyzed retrieved liners were only for an average of 13.1 months in situ and the in vitro test simulated approximately 2.9 years of in vivo service life. As retrieval studies from other acetabular cup designs have demonstrated a significant correlation between backside damage and age in vivo for CPE and XLPE liners [12,13], it is important to investigate if the backside wear increases on vitamin E blended polyethylene liners with the mentioned locking mechanism through time. To date, no long-term retrievals of vitamin E blended polyethylene are available, therefore, only in vitro studies can provide information regarding their performance at the long-term.

\section{Objectives}

The purpose of our study was to obtain a picture of the overall wear (articulation and backside surfaces) of $0.1 \%$ vitamin $E$ blended polyethylene liners with a press-fit locking mechanism under a 20 million cycles hip wear simulation, equivalent to approximately 11.4 years in vivo service [14]. More specifically, our purposes were to analyze the backside wear of the liners, which wear modes can be expected and if this type of wear increases with time.

\section{Materials and Methods}

\section{In vitro wear simulation}

In vitro wear simulation was performed on a customized $6+2$ (reference) stations servohydraulic hip simulator (EndoLab GmbH, Thansau, Germany) with kinematic and load patterns according to ISO 142421:2014(E). Acetabular cups (Plasmafit ${ }^{\circledR}$ Poly Cup, size 50, Aesculap AG, Tuttlingen, Germany) made out of Ti6Al4V alloy and without screw drill holes were used in combination with highly cross-linked (electron beam, $80 \mathrm{kGy})$, vitamin E (0.1\%) blended and EO sterilized polyethylene liners (Plasmafit ${ }^{\circledR}$ Poly Insert, size $36 \mathrm{~mm}$, Aesculap AG, Tuttlingen, Germany). Modular heads of $36 \mathrm{~mm}$ (taper 12/14) made out of zirconia toughened alumina ceramic (BIOLOX ${ }^{\circledR}$ delta, Aesculap AG, Tuttlingen, Germany) were used for the articulation.

Prior wear simulation, all the polyethylene liners were subjected to artificial aging according to ASTM F2003-02 in a heat-conditioning chamber at $70^{\circ} \mathrm{C}$ in pure oxygen and at 5 bar for two weeks (BM400, Memmert GmbH + Co. KG, Schwabach, Germany). Afterwards, the polyethylene liners were soaked in serum-based test medium until the incremental mass change over 24 hours was less than $10 \%$ of the previous cumulative mass change (34 days) in order to allow for saturated fluid absorption according to ISO 14242-2:2016(E).

Wear simulation was performed for 20 million cycles at a frequency of $1 \mathrm{~Hz}$ in a test medium at $37^{\circ} \mathrm{C}$ consisting of newborn calf serum (Biowest SAS, Nuaille, France) diluted with deionized water in order to achieve a protein concentration of $30 \mathrm{~g} /$ l. Ethylene diamine tetraacetic acid and Amphotericin B were added to the test medium in order to stabilize the $p \mathrm{H}$ and prevent fungal decay, respectively. The test medium was replaced at 0.5 million cycles intervals and all the components were cleaned with deionized water and mild soap without removing the polyethylene liners from the acetabular cup in order to reduce potential backside wear produced by the constant removing and insertion of the liner. Only every 5 million cycles the polyethylene liners were removed from the acetabular cups and cleaned according to ISO 14242-2:2016(E). After every 0.5 million cycles, the component sets were rotated across stations to minimize the effect of inter-station kinematic variability. For the different analysis, two groups were defined: "Reference" liners $(n=2)$ subjected only to axial load; and "Wear simulated" liners $(\mathrm{n}=6)$ subjected to axial load and movement.

\section{Wear at the articulation surface and geometrical changes}

Optical analysis of the articulation surface of the polyethylene liners was performed after 5,10 , 15 and 20 million cycles using a digital microscope (VHX-5000, Keyence Corporation, Osaka, Japan) with a 30- and 50-fold magnification. Plastic deformation due to creep and wear was assessed by means of a three-dimensional measuring machine (UMM850, Carl Zeiss AG, Oberkochen, Germany) in a tactile measuring mode (1500 points per scan). The geometrical changes were displayed vertically to the transversal plane of the polyethylene liners with a pseudocolor mode.

\section{Optical backside wear analysis}

Optical analysis of the backside surface of the polyethylene liners was performed after $5,10,15$ and 20 million cycles using the digital microscope previously mentioned with a 50 -fold magnification. A semi-quantitative method developed by Hood et al. [15] and modified for hip implants was used to assess the damage on the backside of the liners. The detailed description of the modified method is given in the previously performed study [11] and will be briefly summarized in the following. On basis of its in situ orientation, the backside section was divided by a superior / inferior line and 7 different sections were determined (Figure 1).

For each section, a score between 0 and 3 was given for each of the seven different wear modes (deformation, pitting, embedded particles, scratching, burnishing, abrasion and delamination), giving a maximum possible damage score of 21 per section. A score of 0 meant no damage; a score of 1 meant damage to less than $10 \%$ of the surface area, 2 meant damage to $10-$ 
$50 \%$ of the surface area and 3 meant that more than $50 \%$ of the area had been damaged. Each component was given a total damage score based on the sum of the scores from all its seven sections. The maximum possible damage score was 147 .

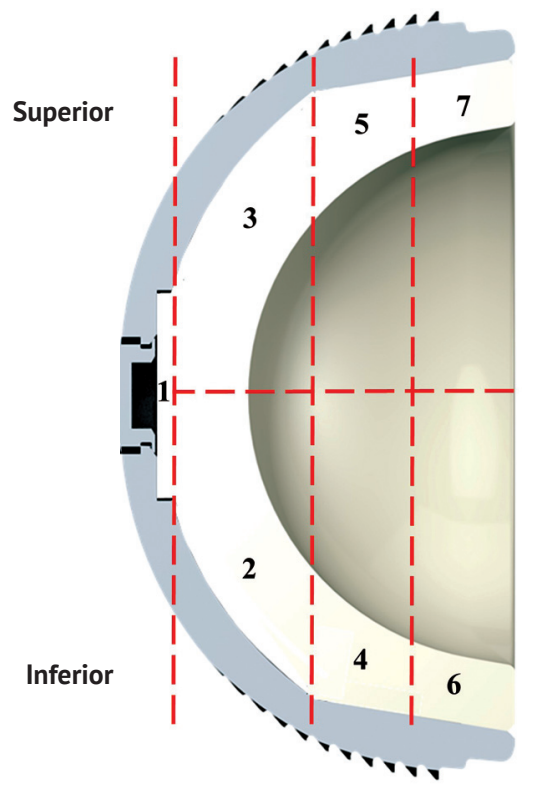

Fig. 1. Sketch

from a crosssection of a Plasmafit ${ }^{\circledR}$ liner with its titanium alloy shell and the corresponding sections for backside wear analysis [11]

The optical analysis was performed by two of the authors (ALPR, MH) and their scores were averaged. Both observers were blinded to previous results at the time of new scoring and to the results of the other observer. The inter-observer reliability of this method was "substantial", with kappa measures ranging between 0.62 and 0.72 .

\section{Statistics}

To differentiate the average total backside wear scores after 5, 10, 15 and 20 million cycles of the "Wear simulated" and "Reference" liners, an analysis of variance was carried out $(p=0.05)$ followed by a post hoc test (Scheffe $p=0.05$ ). To differentiate between the "Wear simulated" and "Reference" liners at 5, 10, 15 and 20 million cycles, an analysis of variance $(p=0.05)$ was carried out followed by a post hoc test (HSD Test for unequal $\mathrm{N}, \mathrm{p}=0.05)$. Prior to analysis, the normal distribution (p-p plots) and the homogeneity of variance (Levene Test) were verified (Dell Statistica R13, Dell Inc., Hamburg, Germany). A p value less than 0.05 was considered as significant.

\section{Results}

\section{Wear at the articulation surface and geometrical changes}

Optical analysis of the wear patterns at the articulation surface of the "Wear simulated" liners showed an increment in the total wear area through the
20 million cycles (Figure 2). The wear modes seen at the articulation area during the whole test were burnishing and slight scratches. After the first 5 million cycles, even though there was burnishing of the surface, the machining marks at the pole of the articulation surface could still be slightly seen. However, these were erased through the rest of the wear simulation and were not seen at the end of the test. The superior side of the liner showed high burnishing since the first 5 million cycles, whereas the inferior side showed practically no wear marks after the first 5 million cycles, but showed burnishing of the surface through time. Regarding the "Reference" liners that underwent just to axial load, no burnishing nor scratches were seen through the entire simulation, as the machining marks were always clearly visible (Figure 3).

The 3D analysis performed on the "Wear simulated" liners after 20 million cycles showed a total head penetration generated by creep and wear of $107.4 \pm 31.0 \mu \mathrm{m}$, whereas the "Reference" liners had a total head penetration only by creep of $33.4 \pm 7.8 \mu \mathrm{m}$ (Figure 4). Hence, approximately one third of the total head penetration of the "Wear simulated" liners was a result of plastic deformation.

\section{Optical backside wear analysis}

After 5 million cycles, the "Wear simulated" liners had a total average backside wear score of $22.00 \pm 2.59$ (from a maximum total score of 147), which was statistically lower than the scores at 10 million cycles $(31.92 \pm 5.57, \mathrm{p}<0.001), 15$ million cycles $(27.50 \pm 2.58, \mathrm{p}=0.005)$, and 20 million cycles $(30.00 \pm 2.52, \mathrm{p}<0.001)$. Moreover, there was a statistical decrease in the total average backside wear score from 10 to 15 million cycles $(p=0.04)$, but there was no statistical change from 15 to 20 million cycles $(p=0.41)$. The reason for the decrease in the total average backside wear score will be discussed in the following section.

On the other hand, the "Reference" liners subjected only to axial load had a total average backside wear score of $16.50 \pm 2.52$ after 5 million cycles, which was also statistically lower than the scores at 10 million cycles $(26.75 \pm 2.63, \mathrm{p}<0.001), 15$ million cycles $(27.25 \pm 1.26, \mathrm{p}<0.001)$, and 20 million cycles $(24.00 \pm 1.41, p=0.002)$. They did not have any significant change from 10 to 15 million cycles $(p=0.99)$ nor from 15 to 20 million cycles $(p=0.23)$. Finally, there was a statistical difference between the total backside wear score of the "Wear simulated" liners and the "Reference" at 5 and 20 million cycles $(\mathrm{p}=0.009$ and $\mathrm{p}=0.003$, respectively), but not at 10 and 15 million cycles $(\mathrm{p}=0.17$ and $\mathrm{p}=0.88$, respectively) (Figure 5). 
After 5 million cycles
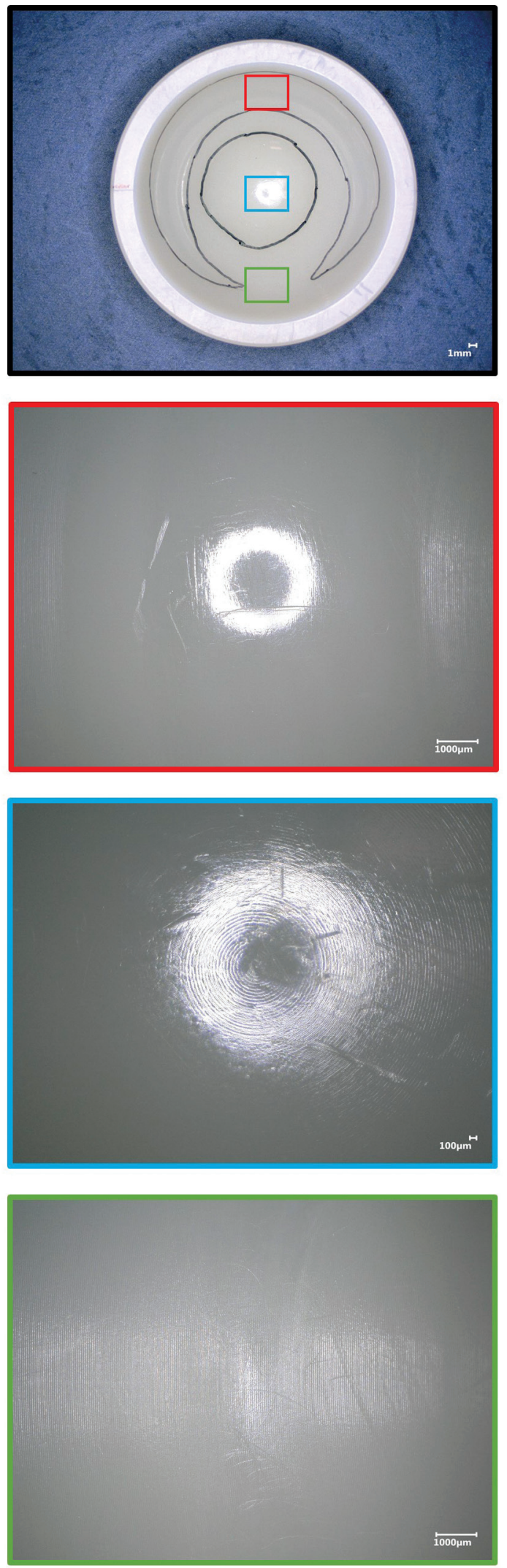

\section{After 20 million cycles}
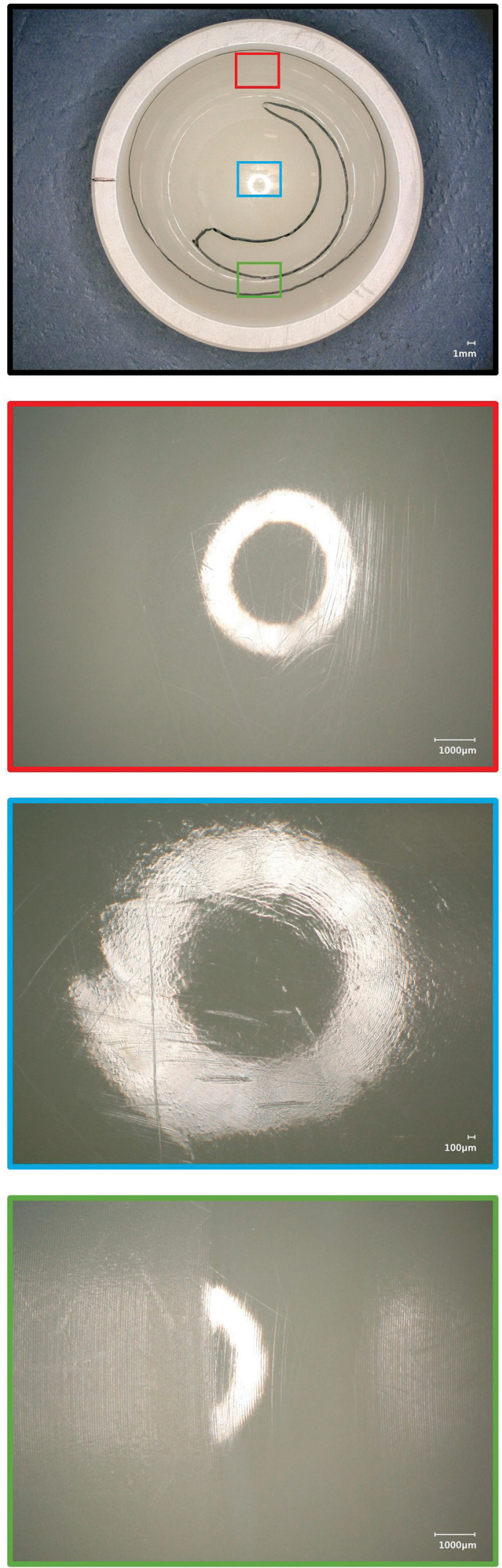

Fig. 2. Wear patterns at the articulation surface of a "Wear simulated" liner (subjected to axial load and movement) after 5 and 20 million cycles showing polishing and slight scratches. Black: overview of the wear areas; red: superior side of the liner in anatomical position; blue: wear at the pole; green: wear at the inferior side 

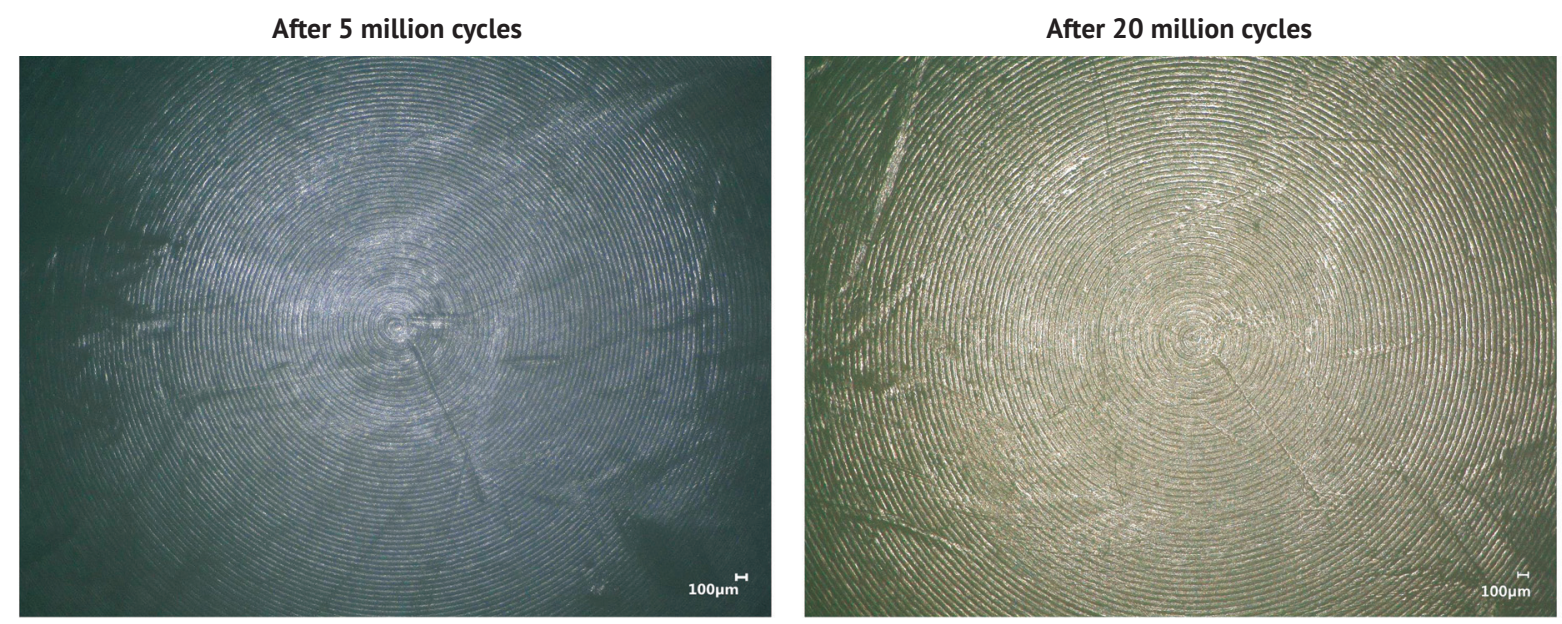

Fig. 3. Articulation surface of a "Reference" liner subjected just to axial load after 5 (left) and 20 (right) million cycles with machining marks still visible
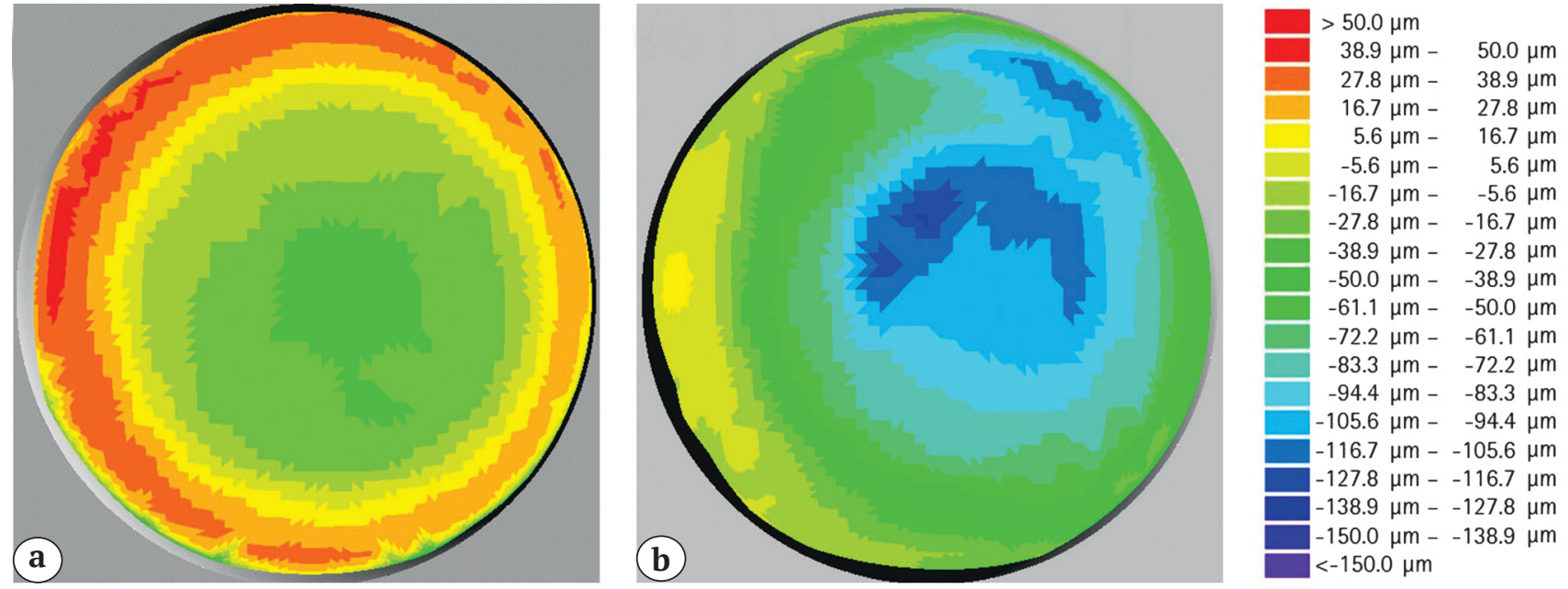

Fig. 4. Geometrical changes after 20 million cycles of a "Reference" liner subjected only to axial load (creep) (a) and a "Wear simulated" liner subjected to axial load and movement (creep and wear) (b)

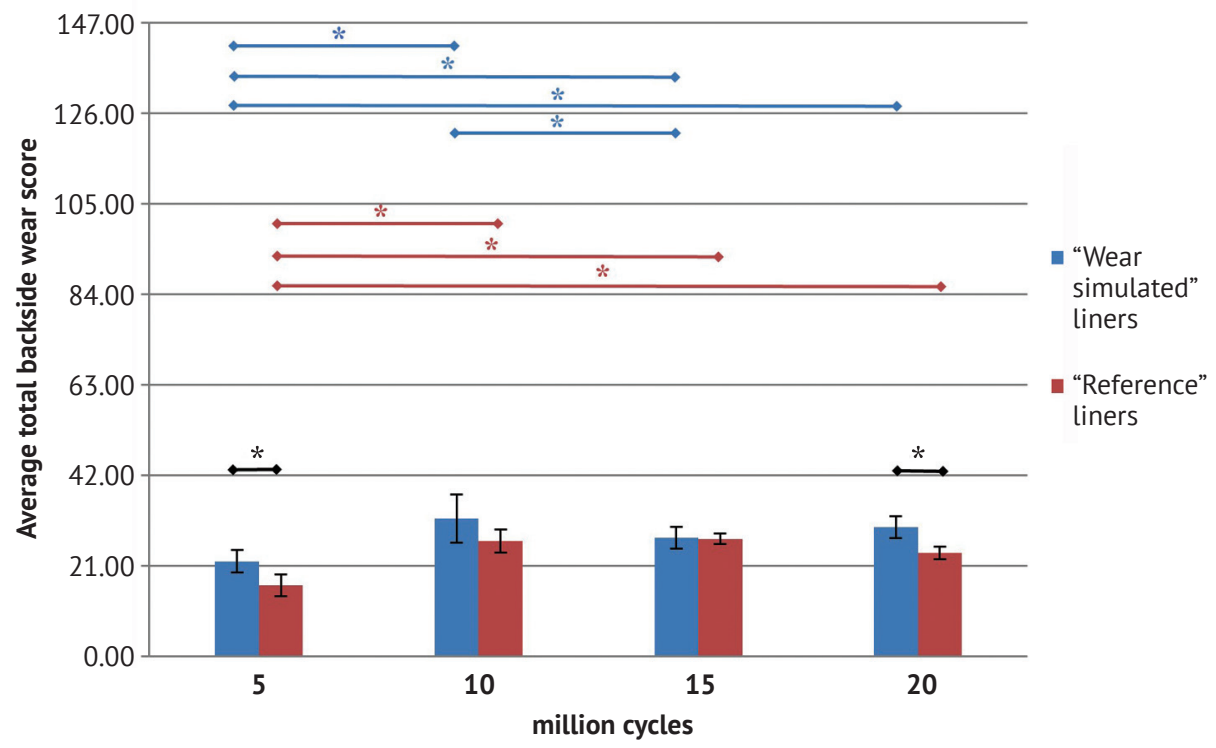

Fig. 5. Average total backside wear score of the "Wear simulated" liners (subjected to axial load and movement) and "Reference" liners (only axial load) after 5, 10, 15 and 20 million cycles.

Maximum total backside wear score possible $=147$.

* Indicates statistical difference $(\mathrm{p}<0.05)$ 
The most common wear mode overall seen after 5 , 10 and 15 million cycles was scratching, followed by burnishing. However, after 20 million cycles, scratching, burnishing and abrasion had approximately the same weight regarding their wear score. Moreover, the number of embedded particles increased through the wear simulation (Figure 6).

When analyzing the wear per sections, those in contact with the milled-drilled smooth acetabular inner surface (sections 1 to 3 ) had the lowest backside wear score (between $2.00 \pm 0.00$ and $4.00 \pm 0.71$ from a maximum score of 21) (Figure 7). In these sections, the main wear mode seen was slight burnishing, as the machining marks appeared flattened. After every 5 million cycles, the machining marks appeared to be more flattened, but were still clearly visible after 20 million cycles. Same tendency was seen on the "Reference" liners (Figure 8).

Regarding the rim of the liners, the highest wear scores were seen in sections 4 and 5 , with values ranging from $4.17 \pm 0.52$ to $7.33 \pm 0.68$. In these sections, the most observed wear mode were small scratches. However, as the test went on, the number of scratches increased and the surface showed abrasion marks.

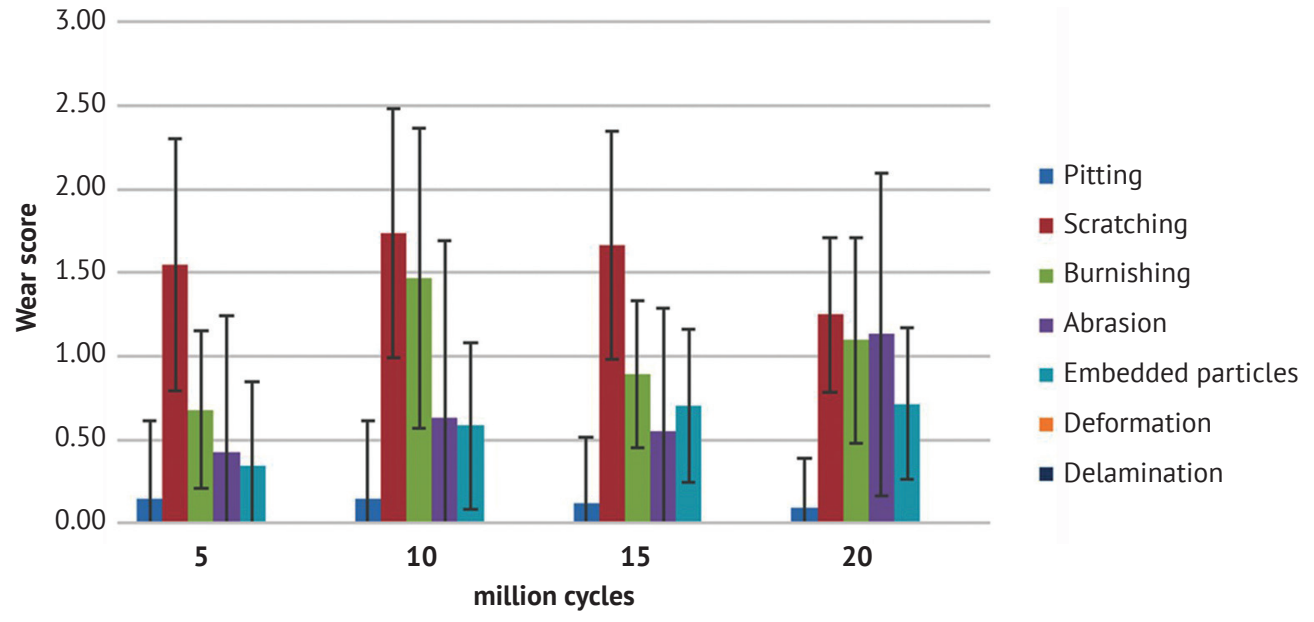

Fig. 6. Average score per wear mode of all backside sections of the "Wear simulated" liners after $5,10,15$ and 20 million cycles. Maximum possible score per wear mode $=3$

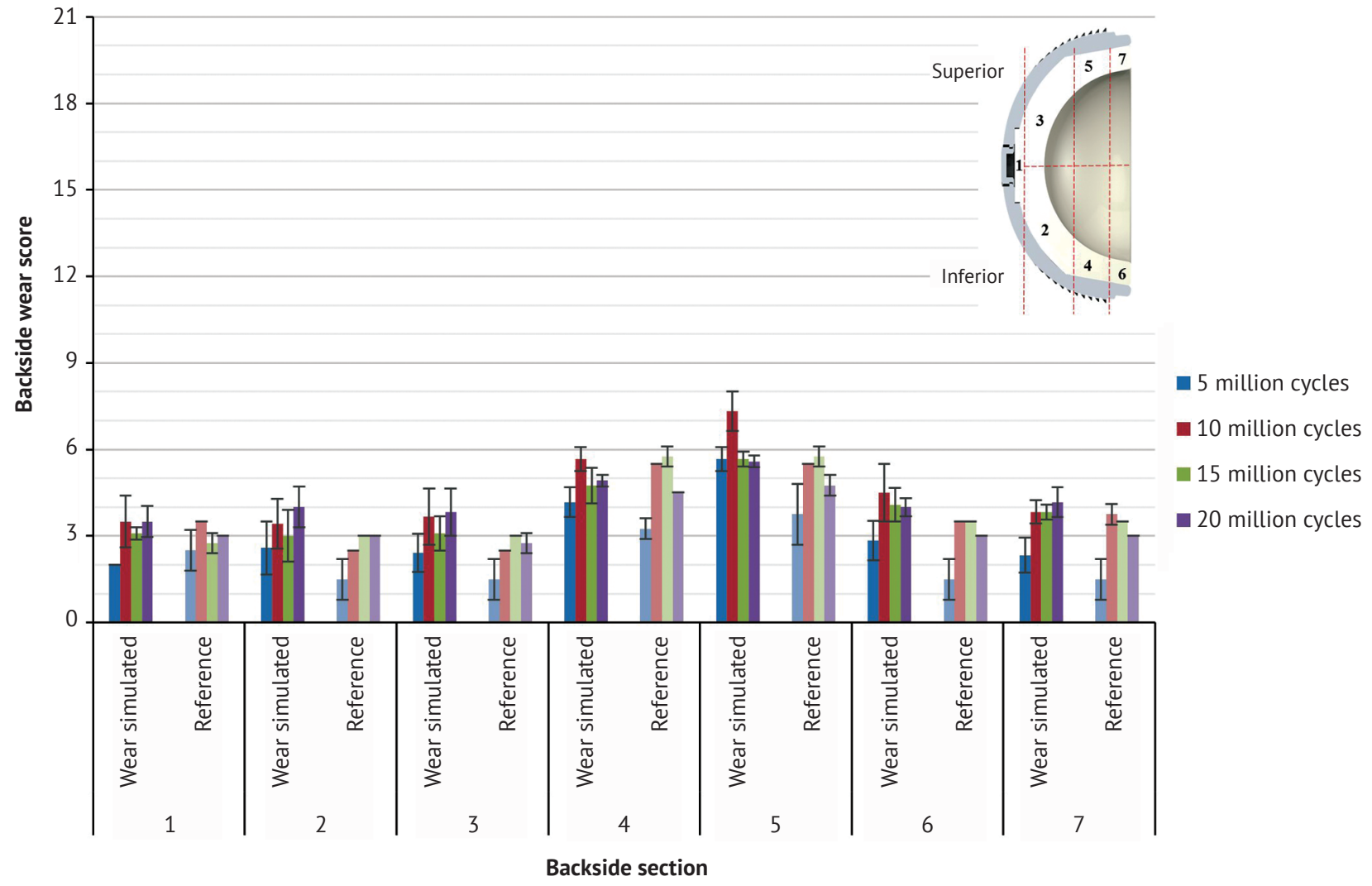

Fig. 7. Backside wear score per backside section for the "Wear simulated" (axial load and movement) and "Reference" liners (only axial load) after 5, 10, 15 and 20 million cycles. Maximum backside wear score per zone $=21$ 
In sections 6 and 7, the surface also showed mainly small scratches and their number also increased through the test, but no abrasion in these zones was seen. The same tendency was seen in the "Reference" liners (Figure 9).
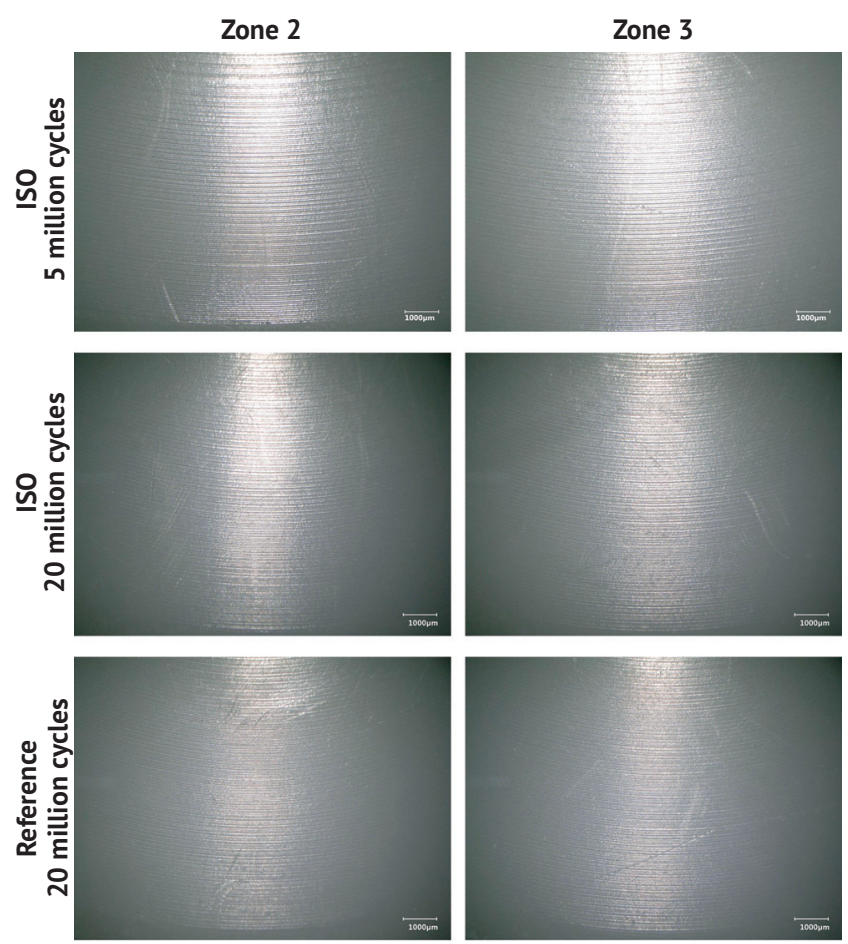

Fig. 8. Representative images of backside zones 2 and 3 of a "Wear simulated" liner after 5 and 20 million cycles (axial load and movement) and a "Reference" liner after 20 million cycles (only axial load). Machining marks were always visible

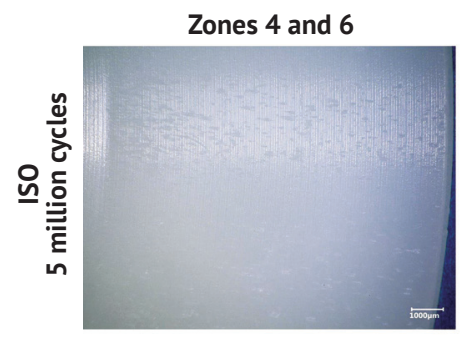

Zones 5 and 7
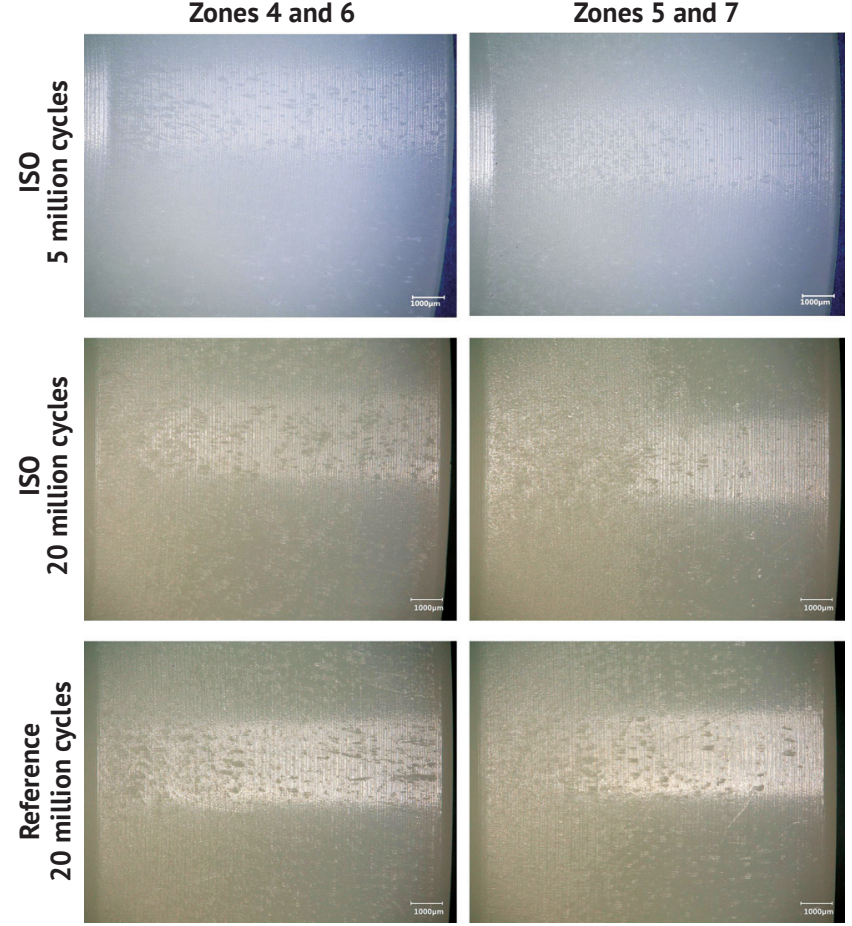

\section{Discussion}

The purpose of our study was to obtain a picture of the overall wear (articulation and backside surfaces) of $0.1 \%$ vitamin $\mathrm{E}$ blended polyethylene liners with a press-fit locking mechanism under a 20 million cycles hip wear simulation, equivalent to approximately 11.4 years in vivo service [14]. More specifically, our purposes were to analyze the backside wear of the liners, which wear modes can be expected and if this type of wear increases with time. To the authors knowledge, this is the first study to analyze the backside wear of vitamin $\mathrm{E}$ liners in a long-term in vitro wear simulation.

As highly cross-linked polyethylene with vitamin E content (either blended or diffused) is a relatively new material, there are currently no long-term follow-up studies available to compare the results obtained in the current in vitro study. Nevertheless, short-term follow-up studies have shown a similar performance between XLPE liners with and without vitamin E content $[16,17]$. Vitamin $\mathrm{E}$ does not provide additional wear resistance to the polyethylene after highly crosslinking, but prevents its oxidation, and thus it is expected to maintain its excellent wear characteristics through time. For this reason, in vivo results of XLPE liners can be used as a reference to compare the vitamin E liner results of the present in vitro study.

During its in vivo service time, the most common method to measure the wear of polyethylene liners is through measurement of the femoral head penetration by means of $x$-ray images. The highest head penetration occurs during the first year after surgery and is mainly due to creep, which then decreases through time. Follow-up studies have shown an average head penetration between 30 and $50 \mu \mathrm{m}$ on XLPE liners during the first year after surgery $[18,19]$. The reference liners subjected just to axial load of the current in vitro study showed a total head penetration similar to those values. Taking into account an average of 1.76 million gait cycles per year for hip and knee arthroplasty patients [14], and that after approximately one year of implantation there is no considerable creep of the liner, the steady state wear rate of the vitamin E liners from our study was approximately $7 \mu \mathrm{m} / \mathrm{year}$. This wear rate is similar to that found in several mid- and long-term follow-up (7 to 13 years) studies of XLPE

Fig. 9. Representative images of backside zones 4 to 7 of a "Wear simulated" liner after 5 and 20 million cycles (axial load and movement) and a "Reference" liner after 20 million cycles (only axial load).

Small scratches in the direction of insertion and removal were clearly seen. Even though the images correspond to the same "Wear simulated" liner, the color difference was due to a different white balance configuration of the microscope 
liners, where steady state wear rates between 1 and 10 $\mu \mathrm{m} /$ year have been found [19-22], and is considerably below the osteolysis threshold wear rate of $100 \mu \mathrm{m} /$ year [23]. Short-term follow-up studies of XLPE liners with vitamin $\mathrm{E}$ content also show similar wear rates as those from XLPE previously mentioned [16, 17, 24, 25]. However, this excellent wear characteristics of the XLPE at the long-term are in question, as studies have demonstrated in vivo oxidation of annealed XLPE by means of cyclic fatigue loading and fluid absorption, whereas remelting of XLPE leads to a reduction of its mechanical properties [26-30]. Deterioration of the wear properties of vitamin E blended highly crosslinked polyethylene liners as a consequence of material oxidation is not expected to occur in the longterm, as previous in vitro studies have demonstrated oxidation resistance of this material even after severe artificial aging [31, 32].

Regarding the backside wear of our in vitro study, a total average backside wear score of 22 from a maximum of 147 was seen after the first 5 million cycles. After this time, small scratches were seen at the rim of the liner, which were produced during its insertion and removal from the acetabular shell. Nevertheless, the machining lines of the liners were still clearly visible in the rim areas without scratches as well as below the milled-drill smooth surface of the acetabular shell. This demonstrated that there was no micromotion of the liner that could produce burnishing or abrasion on it. The significant increment in the backside wear score seen after 10 million cycles was because of the second insertion and removal of the liner, as this produced more scratches and embedded particles from the rough titanium shell. However, there was no further significant increment in the total average backside wear scores after 15 and 20 million cycles. Furthermore, the machining lines in the rest of the liner just appeared to be more flattened through the test, but were still clearly visible.

Even though a structured method was applied, the visual analysis is based on appreciation and thus, changes in the type of microscope, light, magnification, observer and time lapse between scoring can influence the results. The facts that the observers were blinded to the previous results and that the time lapse between measuring points was approximately 3 months might be the reasons for the statistical drop in total backside wear scores registered from the 10 to 15 million cycles measuring points. The observers did not saw a clear change in the type and degree of wear as from the 5 to 10 million cycles analysis, but they did not had the previous results to influence their scoring. Regardless of the scores, the same wear modes and patterns were seen in the current in vitro study and in our previous retrieval study [11]. A previous study from Pang et al. [33] showed that visual backside damage scoring may not completely correspond with true volumetric wear, as no difference in damage scores were seen between XLPE and CPE liners, but there was three times more penetration in the CPE liners than in the XLPE liners.

Despite the limitations of the visual analysis because of its subjective nature, it was effective to describe the extent of the backside wear and how it developed through time. For example, it was seen that the superior sections of the liner had higher backside wear scores as their counterpart, which correlates to the direction of the joint forces and might also be the reason why the "Wear simulated" liners (subjected to axial load and movement in anatomical position) had a statistical difference with the "Reference" liners (subjected only to axial load), as in the later ones the force was equally distributed. Besides, it was the only tool available in order to measure the backside wear of the liners in a semi-quantitative manner. For instance, it was also pursued to measure the geometrical changes at the backside of the inserts with the 3D measuring machine used for the measurement at the articulation surface, but the backside wear was so low, that no quantitative results could be obtained with such method.

Proven that there is a secure locking mechanism and that there is no severe backside wear, it has been shown that this type of wear does not induce acetabular osteolysis. A retrieval study from Yamaguchi et al. [34] found no correlation between backside deformation and acetabular osteolysis, but a significant association between pelvic or femoral osteolysis and linear wear at the articulation surface. On the other hand, Akbari et al. [12] found no backside wear on CPE liners retrieved due to osteolysis, only partial flattening of the machining marks as in our current in vitro study. Furthermore, all the osteolytic cysts found at surgery were peripheral. Moreover, Bali et al. [13] suggested that XLPE is more resistant to backside damage than $\mathrm{CPE}$, as a similar backside damage score was found on XLPE liners with different locking mechanism, contrary to the CPE, which had different scorings depending on the locking mechanism.

Studies have already shown that backside wear is considerable low compared with the wear at the articulation surface. For instance, Kurtz et al. [9] demonstrated that the backside linear and volumetric wear rates were three orders of magnitude less than wear estimates at the articulating surface, which was attributed to the difference in maximum sliding distances at the articulating surface (measured in $\mathrm{mm}$ ) versus the back surface (measured in $\mu \mathrm{m}$ ). Moreover, Krieg et al. [35] showed that the rate of backside volumetric change (predominantly creep) was only $2.8 \%$ of the rate of volumetric articular wear. Although some data suggest that a functional locking mechanism at the acetabular shell-liner interface is a major factor to reduce backside wear, other aspects concerning the 
acetabular socket design have to be considered when evaluating the properties of an implant for clinical application [13]. It is evident that the clinical outcome is not only dependent on the amount of backside wear but also on the amount and type of wear particles which migrate behind the acetabular shell through the screw holes inducing aseptic loosening. Here, the significance of micro-pumping mechanisms and the application of screw holes promoting osteolysis in cementless cups is controversially discussed in the literature and needs to be investigated in the future [36-38]. The acetabular socket design of the present study lacks of screw hole drills, and thus reduces the potential migration of backside wear particles behind the acetabular shell through these screw holes.

In summary, two facts from the present study demonstrated that wear occurred predominantly at the articulation surface in the long-term in vitro wear simulation. First, there was increased burnishing through the test at the articulation area of the "Wear simulated" liners (subjected to axial load and movement), whereas the "Reference" liners (subjected just to axial load) showed no wear at all. Second, the backside wear of the "Wear simulated" liners, even though it was statistically different at 5 and 20 million cycles, was similar to that of the "Reference" liners, demonstrating that most of the backside wear was produced during their insertion and removal from the acetabular shell. As the wear rate found at the articulation surface of the in vitro tested vitamin $\mathrm{E}$ liners is one to two orders of magnitude lower than the osteolysis threshold, no acetabular osteolysis as a consequence of backside wear can be expected. Regarding its clinical performance at the long-term, the Danish Hip Arthroplasty Register from 2014 [39] reported a survival rate of $94.1 \%$ at 10 years for all reasons of cup revision and 99.3\% at 10 years with aseptic loosening as endpoint for the previous model of the acetabular system here described, which has the same locking mechanism as the one in the present study. Long-term retrievals or follow-up studies will be needed in order to validate the current in vitro results.

\section{Conclusions}

The present study showed that wear at the articulation surface was far below the osteolysis threshold on highly cross-linked and $0.1 \%$ vitamin $\mathrm{E}$ blended polyethylene liners and confirmed that there was little to no micro-motion at its interface between the acetabular shell in a long-term hip wear simulation. Furthermore, it was demonstrated that most of the backside wear produced on the liners occurred during their insertion and removal rather than during their life in service and that there was no significant increment of this type of wear through time. Finally, longterm retrieval analysis will be needed in order to validate this in vitro results.

\section{Declaration}

Competing interests: Four of the authors (ALPR, $\mathrm{MH}, \mathrm{CS}, \mathrm{TMG}$ ) are employees of Aesculap AG Tuttlingen, a manufacturer of orthopaedic implants. One of the authors (MJ) is an advising surgeon of Aesculap R\&D projects and is receiving institutional research funding in correlation with Aesculap R\&D projects.

Funding: none.

Ethical approval: not required.

Acknowledgements: none.

\section{References}

1. Sadoghi P., Liebensteiner M., Agreiter M., Leithner A., Böhler N., Labek G. Revision surgery after total joint arthroplasty: a complication-based analysis using worldwide arthroplasty registers. J Arthroplasty. 2013;28(8):1329-1332. DOI: 10.1016/j.arth.2013.01.012.

2. Nieuwenhuis J.J., Malefijt J. de W., Hendriks J.C., Gosens T., Bonnet M. Unsatisfactory results with the cementless Omnifit acetabular component due to polyethylene and severe osteolysis. Acta Orthop Belg. 2005;71(3):294-302.

3. Noble P.C., Durrani S.K., Usrey M.M., Mathis K.B., Bardakos N.V. Constrained cups appear incapable of meeting the demands of revision THA. Clin Orthop Relat Res. 2012;470(7):1907-1916.

DOI: $10.1007 / \mathrm{s} 11999-011-2212-4$.

4. Powers C.C., Ho H., Beykirch S.E., Huynh C., Hopper R.H. Jr., Engh C.A. Jr., Engh C.A. A comparison of a secondand a third-generation modular cup design: is new improved? J Arthroplasty. 2010;25(4):514-521. DOI: 10.1016/j.arth.2009.02.018.

5. Wasielewski R.C., Jacobs J.J., Arthurs B., Rubash H.E. The acetabular insert-metal backing interface: an additional source of polyethylene wear debris. J Arthroplasty. 2005;20(7):914-922. DOI: 10.1016/j.arth.2005.04.033.

6. Kawaji H., Koistinen A., Korhonen R., Lappalainen R., Lohman M., Soininen A. et al. Back-side wear in HexLoc cups clinico-radiological, immunohistopathological, finite element, and retrieval analysis studies. J Long Term Eff Med Implants. 2014;24(4):319-331.

7. Kurtz S.M., Ochoa J.A., White C.V., Srivastav S., Cournoyer J. Backside nonconformity and locking restraints affect liner/shell load transfer mechanisms and relative motion in modular acetabular components for total hip replacement. J Biomech. 1998;31(5):431-437.

8. Kligman M., Furman B.D., Padgett D.E., Wright T.M. Impingement contributes to backside wear and screwmetallic shell fretting in modular acetabular cups. J Arthroplasty. 2007;22(2):258-264. DOI: $10.1016 /$ j.arth.2005.01.025.

9. Kurtz S.M., Ochoa J.A., Hovey C.B., White C.V.Simulation of initial frontside and backside wear rates in a modular acetabular component with multiple screw holes. J Biomech. 1999;32(9):967-976.

10. Khalily C., Tanner M.G., Williams V.G., Whiteside L.A. Effect of locking mechanism on fluid and particle flow through modular acetabular components. J Arthroplasty. 1998;13(3):254-258.

11. Puente Reyna A.L., Jäger M., Floerkemeier T., Frecher S., Delank K.S., Schilling C., Grupp T.M. Backside wear analysis of retrieved acetabular liners with a press- 
fit locking mechanism in comparison to wear simulation in vitro. Biomed Res Int. 2016;2016:8687131.

DOI: $10.1155 / 2016 / 8687131$.

12. Akbari A., Roy M.E., Whiteside L.A., Katerberg B.J., Schnettgoecke D.J. Minimal backside surface changes observed in retrieved acetabular liners. J Arthroplasty. 2011;26(5):686-692. DOI: 10.1016/j.arth.2010.07.012.

13. Bali K., McCalden R.W., Naudie D.D., MacDonald S.J., Teeter M.G. Backside Wear Is Not Dependent on the Acetabular Socket Design in Crosslinked Polyethylene Liners. Clin Orthop Relat Res. 2016;474(2):374-382. DOI: 10.1007/s11999-015-4471-y.

14. Schwiesau J., Schilling C., Kaddick C., Utzschneider S., Jansson V., Fritz B. et al. Definition and evaluation of testing scenarios for knee wear simulation under conditions of highly demanding daily activities. Med Eng Phys. 2013;35(5):591-600.

DOI: 10.1016/j.medengphy.2012.07.003.

15. Hood R.W., Wright T.M., Burstein A.H. Retrieval analysis of total knee prostheses: a method and its application to 48 total condylar prostheses. J Biomed Mater Res. 1983;17(5):829-842. DOI: 10.1002/jbm.820170510.

16. Nebergall A.K., Greene M.E., Laursen M.B., Nielsen P.T., Malchau H., Troelsen A. Vitamin E diffused highly crosslinked polyethylene in total hip arthroplasty at five years: a randomised controlled trial using radiostereometric analysis. Bone Joint J. 2017;99-B(5):577-584.

DOI: 10.1302/0301-620X.99B5.37521.

17. Sillesen N.H., Greene M.E., Nebergall A.K., Huddleston J.I., Emerson R., Gebuhr P. et al. 3-year follow-up of a long-term registry-based multicentre study on vitamin E diffused polyethylene in total hip replacement. Hip Int. 2016;26(1):97-103. DOI: 10.5301/hipint.5000297.

18. Hagio K., Saito M., Okawa T., Moriyama S., Nakamura Y., Naito M. Polyethylene wear associated with 26- and 32-mm heads in total hip arthroplasty: a multicenter, prospective study. J Arthroplasty. 2016;31(12):28052809. DOI: 10.1016/j.arth.2016.05.063.

19. Nebergall A.K., Greene M.E., Rubash H., Malchau H., Troelsen A., Rolfson O. Thirteen-year evaluation of highly cross-linked polyethylene articulating with either $28-\mathrm{mm}$ or 36-mm femoral heads using radiostereometric analysis and computerized tomography. J Arthroplasty. 2016;31(9 Suppl):269-276.

DOI: 10.1016/j.arth.2016.02.076.

20. Lee J.H., Lee B.W., Lee B.J., Kim S.Y. Midterm results of primary total hip arthroplasty using highly crosslinked polyethylene: minimum 7-year follow-up study. J Arthroplasty. 2011;26(7):1014-1049.

DOI: 10.1016/j.arth.2011.03.015.

21. Glyn-Jones S., Thomas G.E., Garfjeld-Roberts P., Gundle R., Taylor A., McLardy-Smith P., Murray D.W. The John Charnley Award: Highly crosslinked polyethylene in total hip arthroplasty decreases long-term wear: a double-blind randomized trial. Clin Orthop Relat Res. 2015;473(2):432-438. DOI: 10.1007/s11999-014-3735-2.

22. Johanson P.E., Digas G., Herberts P., Thanner J., Kärrholm J. Highly crosslinked polyethylene does not reduce aseptic loosening in cemented THA 10-year findings of a randomized study. Clin Orthop Relat Res. 2012;470(11):3083-3093. DOI: $10.1007 / \mathrm{s} 11999-012-2400-\mathrm{x}$

23. Dumbleton J.H., Manley M.T., Edidin A.A. A literature review of the association between wear rate and osteolysis in total hip arthroplasty. I Arthroplasty. 2002;17(5):649-661.

24. Shareghi B., Johanson P.E., Kärrholm J. Wear of Vitamin E-Infused Highly Cross-Linked Polyethylene at Five
Years. J Bone Joint Surg Am. 20176;99(17):1447-1452. DOI: $10.2106 / J B J S .16 .00691$.

25. Scemama C., Anract P., Dumaine V., Babinet A., Courpied J.P., Hamadouche M. Does vitamin E-blended polyethylene reduce wear in primary total hip arthroplasty: a blinded randomised clinical trial. Int Orthop. 2017 Jun;41(6):1113-1118. DOI: $10.1007 / \mathrm{s} 00264-016-3320-2$.

26. Oral E., Wannomae K.K., Hawkins N., Harris W.H., Muratoglu O.K. Alpha-tocopherol-doped irradiated UHMWPE for high fatigue resistance and low wear. Biomaterials. 2004;25(24):5515-5522.

DOI: 10.1016/j.biomaterials.2003.12.048.

27. Oral E., Muratoglu O.K. Vitamin E diffused, highly crosslinked UHMWPE: a review. Int Orthop. 2011; 35(2):215-223. DOI: 10.1007/s00264-010-1161-y.

28. Muratoglu O.K., Wannomae K.K., Rowell S.L., Micheli B.R., Malchau H. Ex vivo stability loss of irradiated and melted ultra-high molecular weight polyethylene. J Bone Joint Surg Am. 2010;92(17):28092816. DOI: 10.2106/JBJS.I.01017.

29. Kurtz S.M., Hozack W.J., Purtill J.J., Marcolongo M., Kraay M.J., Goldberg V.M. et al. 2006 Otto Aufranc Award Paper: significance of in vivo degradation for polyethylene in total hip arthroplasty. Clin Orthop Relat Res. 2006;453: 47-57. DOI: 10.1097/01.blo.0000246547.18187.0b.

30. Wannomae K.K., Bhattacharyya S., Freiberg A., Estok D., Harris W.H., Muratoglu O. In vivo oxidation of retrieved cross-linked ultra-high-molecular-weight polyethylene acetabular components with residual free radicals. J Arthroplasty. 2006;21(7):1005-1011.

31. Grupp T.M., Holderied M., Mulliez M.A., Streller R., Jäger M., Blömer W., Utzschneider S. Biotribology of a vitamin E-stabilized polyethylene for hip arthroplasty Influence of artificial ageing and third-body particles on wear. Acta Biomater. 2014;10(7):3068-3078. DOI: $10.1016 /$ j.actbio.2014.02.052.

32. Popoola O.O., Mimnaugh K., Orozco-Villasenor D.A., Peiserich M. Vitamin E-grafted crosslinked ultrahighmolecular weight polyethylene (VE-HXPE) inhibits fluid absorption and has long term oxidative stability. Biotribology. 2015;4:12-17. DOI: 10.1016/j.biotri.2015.09.006.

33. Pang H.N., Naudie D.D., McCalden R.W., MacDonald S.J., Teeter M.G. Highly crosslinked polyethylene improves wear but not surface damage in retrieved acetabular liners. Clin Orthop Relat Res. 2015;473(2):463-468. DOI: 10.1007/s11999-014-3858-5.

34. Yamaguchi M., Bauer T.W., Hashimoto Y. Deformation of the acetabular polyethylene liner and the backside gap. J Arthroplasty. 1999;14(4):464-469.

35. Krieg A.H., Speth B.M., Ochsner P.E. Backside volumetric change in the polyethylene of uncemented acetabular components. J Bone Joint Surg Br. 2009;91(8):1037-1043. DOI: 10.1302/0301-620X.91B8.21850.

36. Taniguchi N., Jinno T., Takada R., Koga D., Ando T., Okawa A., Haro H. Do screws and screw holes affect osteolysis in cementless cups using highly crosslinked polyethylene? A 7 to 10-year follow-up case-control study. Orthop Traumatol Surg Res. 2018 Jan 30. pii: S1877-0568(18)30023-9. DOI: 10.1016/j.otsr.2017.12.009.

37. Urban R.M., Hall D.J., Della Valle C., Wimmer M.A., Jacobs J.J., Galante J.O. Successful long-term fixation and progression of osteolysis associated with firstgeneration cementless acetabular components retrieved post mortem. J Bone Joint Surg Am. 2012;94(20):18771885. DOI: 10.2106/JBJS.J.01507. 
38. Schmalzried T.P., Brown I.C., Amstutz H.C., Engh C.A., Harris W.H. The role of acetabular component screw holes and/or screws in the development of pelvic osteolysis. Proc Inst Mech Eng H. 1999;213(2): 147-153.

\section{INFORMATION ABOUT AUTHORS:}

Ana Laura Puente Reyna - Research Engineer, Aesculap AG, Tuttlingen; PhD Student (Ludwig Maximilians University), Munich, Germany

Melanie Holderied - Research Engineer, Aesculap AG, Tuttlingen, Germany

Marcus Jäger - Dr. med., Univ.-Prof., Clinic Director University of Duisburg-Essen Department of Orthopaedics and Trauma Surgery, Essen, Germany

Christoph Schilling - Dr. rer. medic. Dipl.-Ing., Expert Engineer, Aesculap AG, Tuttlingen, Germany

Thomas M. Grupp - Dr. med., Principal Expert Engineer, Aescualp AG, Tuttlingen; Associate Professor of Experimental Orthopaedics and Biomechanics, Ludwig Maximilians University, Munich, Germany
39. Dansk Hoftealloplastik Register: National Årsrapport 2014 [Danish Hip Arthroplasty Register: National Annual Report 2014]. Available at: http://danskhoftealloplastikregister. dk/wp-content/uploads/2015/11/DHR-årsrapport-2014. pdf. (in Danish).

\section{ИНФОРМАЦИЯ ОБ АВТОРАХ:}

Ana Laura Puente Reyna - инженер-исследователь, Aesculap AG, Тутлинген; аспирант, Университет им. Людвига Максимилиана, Мюнхен, Германия

Melanie Holderied - инженер-исследователь, Aesculap AG, Тутлинген, Германия

Marcus Jäger - д-р медицины, профессор университета, клинический директор, отделение травматологии и ортопедии, Университет Дуйсбург-Ессен, Ессен, Германия

Christoph Schilling - д-р медицины, инженер-эксперт, Aesculap AG, Тутлинген, Германия

Thomas M. Grupp - д-р медицины, главный инженерэксперт, Aesculap AG, Тутлинген; доцент кафедры экспериментальной ортопедии и биомеханики, Университет им. Людвига Максимилиана, Мюнхен, Германия 